\title{
Proposed AIDS screening causes political turmoil in France
}

\section{Paris}

AN ill-timed proposal for systematic screening for the AIDS virus in pregnant women and patients due to undergo surgery was at the heart of a controversy that rocked the new French government last month. As the newly elected socialists struggle with a hung parliament, this affair shows not only that AIDS is a politically sensitive issue, but that the government's strategy for opening access to power for non-career politicans may not be the way to get the support it needs to govern.

Just nine days after he appointed his new government - for the second time in under two months - Prime Minister Michel Rocard found himself forced to demand the resignation of two of his junior ministers, both of them new to politics. One of these, Leon Schwartzenberg, a practising haematologist who sees himself as a crusader for patients' rights, found that his first lesson in political protocol, the need to consult his peers, will benefit his successor more than himself.

Schwartzenberg was given the health portfolio under Claude Evin, minister for solidarity, health and social security. At his first press conference on 5 July, Schwartzenberg surprised and embarrassed the government by unveiling plans for systematic screening for AIDS, criminal

\section{Companies to pay in toxic clean-up accord}

\section{Boston}

THE US Environmental Protection Agency (EPA) announced last week the largest single cash settlement from the highest number of companies in the history of the federal toxic waste cleanup programme called Superfund. In the agreement, more than 350 companies will pay a total of $\$ 49$ million - \$17 million of it in cash payments to EPA - to clean up four sites in Massachusetts and New Hampshire where a private disposal company illegally dumped toxic waste.

Years of midnight dumping by the Cannons Engineering Corporation left a legacy of more than 180,000 cubic feet of soil contaminated with hundreds of thousands of gallons of liquid waste oils, solvents and other toxins. In the EPA settlement, area companies using the Cannons waste management company will have to pay the bulk of the clean-up because the Superfund law makes waste generators responsible for their toxic waste from 'cradle to grave'. The settlement awaits official authorization from a federal judge, and also leaves outstanding a dispute over $\$ 9$ million in further costs against 25 companies that have refused to pay for the clean-up.

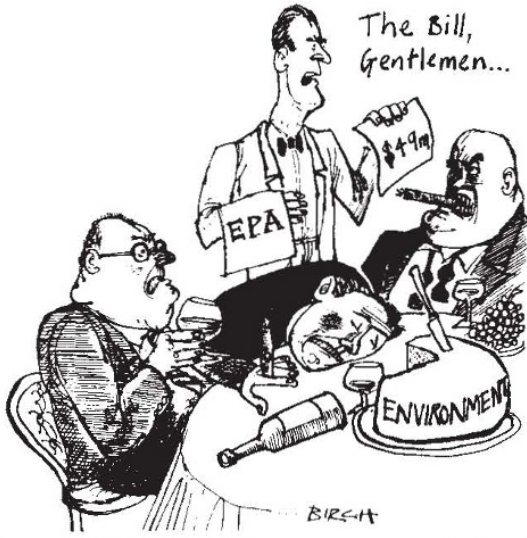
dumping face gaol sentences. proceedings against employers who discriminate against seropositive employees, the introduction of measures to combat drug addiction and an obligation for doctors to give patients a copy of their medical records after each treatment. These plans had not been discussed with Evin nor with medical colleagues.

In an attempt to restore decorum, Evin immediately announced that Schwartzenberg's proposals would be put before the national ethics committee, as well as two national medical committees, before being taken further. Within 24 hours it was clear that Schwartzenberg did not have the support of his peers. An epidemiological study of AIDS in pregnant women had already suggested that systematic national screening for the virus was not yet justified and could threaten human rights It also emerged that patients have had a statutory right to see their medical records since 1970.

By 7 July, 48 hours after his first press conference, Schwartzenberg had resigned. The prime minister tried to make light of the affair, saying that he respected Schwartzenberg's humanitarianism, but felt that political coherence has to be maintained, but other cabinet members were saying that faux pas could be the price paid for the government's 'demo- cratic' will to open government posts to non-politicians. Members of the opposition were less kind, speaking of "ineptitude" and "government through the media."

Schwartzenerg's return to his post at the Paul-Brousse hospital on the outskirts of Paris may mark the end of the shortestever career of a French politician.

Peter Coles

\section{Nuclear waste policy attacked}

London

BRITAIN's nuclear waste policy has come under severe criticism from the advisers to the government, the Radioactive Waste Management Advisory Committee. In its recent annual report, the committee criticizes aspects of national policy as "confused" and "deficient". And it says that some dumps are not properly monitored because of a lack of resources.

The committee warns that there is "enormous uncertainty" whether a deep disposal site for low and intermediate level waste will be found and in use before the year 2005 as planned, though the disposal site now used for low level waste, at Drigg near Sellafield, in the north of England may be full by 1999 . The chairman of the committee, Professor John Knill of Imperial College, says that British Nuclear Fuels Limited must make more efficient use of the space available or apply for an extension of the disposal area, entailing a planning inquiry.

Intermediate-level waste is presently in

The list of companies entangled in the clean-up mess includes some of the largest corporations in the United States, such as

General Electric, Monsanto and Atlantic Richfield. The list also includes some of the most highly respected local concerns: the Archdiocese of Boston, the Boston Globe newspaper and Polaroid Corporation. Although the waste management company has long since declared bankruptcy, five of the individuals responsible for the actual

Seth Shulman storage pending a decision on an acceptable disposal method. In the meantime there is confusion, says Knill, on how to encapsulate the waste as that is dependent to some extent on the disposal route.

Another item on which policy remains confused is how to dispose of large-scale items from decommissioned nuclear reactors. No decision has yet been taken on whether long-term storage, deep disposal inland or disposal at sea is an appropriate method. This question will become of "increasing urgency" in the next decade, says Knill, "and is just one of many which needs resolution".

Monitoring of dumps for very low-level waste also comes under criticism in the report. The body in charge of administrative and technical controls, Her Majesty's Inspectorate of Pollution, is understaffed, with a heavy workload which may increase in the future, says Knill. As a result, there is no structured programme of monitoring after initial site assessment and sites are not monitored or recorded after closure. This is necessay to protect the sites from accidental intrusion or inappropriate future use, says the report. 